\title{
Risk Management Committee and Textual Risk Disclosure
}

\author{
Eka Sari Ayuningtyas and Iman Harymawan * D
}

\author{
Department of Accounting, Faculty of Economic and Business, Universitas Airlangga, Surabaya 60115, Indonesia; \\ eka.sari.ayuningtyas-2015@feb.unair.ac.id \\ * Correspondence: harymawan.iman@feb.unair.ac.id
}

Citation: Ayuningtyas, Eka Sari, and Iman Harymawan. 2022. Risk

Management Committee and Textual

Risk Disclosure. Risks 10: 30.

https://doi.org/10.3390/risks 10020030

Academic Editor: Mogens Steffensen

Received: 14 December 2021

Accepted: 18 January 2022

Published: 1 February 2022

Publisher's Note: MDPI stays neutral with regard to jurisdictional claims in published maps and institutional affiliations.

Copyright: (c) 2022 by the authors. Licensee MDPI, Basel, Switzerland. This article is an open access article distributed under the terms and conditions of the Creative Commons Attribution (CC BY) license (https:// creativecommons.org/licenses/by/ $4.0 /)$.

\begin{abstract}
This research examines the relationship between the risk management committee and textual risk disclosure. Textual risk disclosure is measured using the use of a risk-contained tone in the annual report. We employed empirical analysis for the Indonesian listed firms for the period 2010 to 2018. The findings of this research suggest that the existence of the risk management committee gives more risk disclosure. This finding implicates that firms with a risk management committee will give more risk disclosure, because they have a specific committee which have abilities concerning firm risk. The first additional analysis suggests that the results are more pronounced for firms within the period after the regulation to have a risk management committee was applied in Indonesia. We also make second additional analysis for different level of technology within industry. The existence of risk management committee for managing risk disclosure is more pronounced for company within high level of technology industry. We provide several contributions to the users of the financial statements such as shareholders and other stakeholders, especially regulatory bodies in Indonesia.
\end{abstract}

Keywords: risk management committee; risk disclosure; tone; MD\&A

\section{Introduction}

Awareness of risk management is increasing, due to many recent corporate business failures and scandals (Walker et al. 2002). Several previous studies have shown that the risk management committee has a function to control, detect, and prevent firm risk (Abdullah and Said 2019; Larasati et al. 2019; Harymawan et al. 2021). Firm risk is divided into two categories. They are the financial risk and non-financial risk. Both of these risks are essential for the stakeholder to be considered in their decision-making. Therefore, companies should pay balanced attention to both of them. Previous studies by (Abdullah and Shukor 2017) proved empirical evidence that existence of a stand-alone risk management committee is positively related to risk management disclosure (Abdullah and Shukor 2017). Besides, the risk management committee also has an impact on non-existence of any financial crime incidence (Abdullah and Said 2019). Harymawan et al. (2021) added that RMC plays a role in monitoring the activities of the company and provides a broader scope for identifying risks within the company. However, to our knowledge, there is lack of empirical evidence on how the existence of a standalone risk management committee affects the firm's risk of textual disclosure.

As is well known, corporate disclosure is one of the crucial things and therefore, mounting studies have focused on examining the quality of corporate disclosure (Harymawan et al. 2020; Putra et al. 2020). Research on qualitative disclosure has existed since the early eighties (Frazier et al. 1984) and has continued to develop until now. The qualitative disclosures have important rules to give a wider perspective to and information for stakeholders, such as investors about the company, especially information that cannot be written in the form of a number. Advances in technology have made this topic more researched. The content analysis method is easier to use with certain applications or software. Several recent studies have examined the tone in company disclosure, especially the MD\&A report, among others (Li 2008; Feldman et al. 2010; Davis and Tama-Sweet 2012; Huang et al. 2014). 
These studies examined whether the tone of various corporate disclosures is related to, for example, the cost of capital, the volatility of returns, and analysts' forecasts (Kothari et al. 2009), shareholder litigation (Rogers et al. 2011), financial reporting errors (Larcker and Zakolyukina 2012), earnings quality (Li 2008), and market prices (e.g., Henry 2008; Li 2008; Feldman et al. 2010; Davis and Tama-Sweet 2012). Kahveci (2016) found that there is a positive relationship between company tone and performance. However, there is still little research concerning how internal factors of a company, such as their corporate governance, affect the qualitative disclosure. Further research needs to be done to find out how the relationship between the two variables is clear, especially in the case of companies in Indonesia.

The preparation of annual reports in Indonesia is regulated by the Financial Services Authority Regulation Number 29/POJK.04/2016 concerning Annual Reports of Go-Public Companies. In the annual report, there are several sections that contain different information. One of the important sections is Management Discussion and Analysis (MD\&A). MD\&A is one part that is mandatory or must be included in the annual report. This section specifically discusses the analysis and management's views on the company's past performance and future plans. Through this report, investors can find out the condition of the company from the manager's point of view. In terms of conveying information, there are several things that need to be considered, one of which is how to write a narrative text. The choice of words and the arrangement of sentences in a report will affect the mindset and point of view of the reader in understanding the information contained therein (Chung and Pennebaker 2011). This is an interesting topic to research. The tone that affects the investor's paradigm in understanding information will later carry over to the decision-making process and can affect the company's future performance.

Based on the Linguistic Theory, a group of words can generally affect the way readers think. In other words, the structure and the use of certain words in a sentence in the text can affect the reader's paradigm in interpreting the meaning of the text. In connection with this theory, there is another theory, namely, the Signaling Theory, which says that the way companies convey information is influenced by the objectives to be achieved, one of which is to give signals to the market. Thus, that tone and readability are important to measure the quality of information in a report.

The tone in a report text is divided into two types, namely, positive and negative. Positive leads more to company optimism, while negative tends to reflect company pessimism. In this study, it will focus on the negative tone that leads to qualitative risk disclosure following previous studies (Kravet and Muslu 2013; Bonsall and Miller 2016). Disclosure of corporate risk in previous studies has shown its effect on investor decisions and company performance (Oyerogba 2019). Risk is usually analyzed using financial analysis, but still, less research analyzes risk disclosure through tone analysis in reporting texts. Most previous studies examined the relationship between corporate governance and bankruptcy risk (Fraile and Fradejas 2012; Darrat et al. 2016; Manzaneque et al. 2016; Seetharaman et al. 2017). However, most previous studies discussed limited samples and examined the effects of several firms' attributes of governance (such as board size and director independence), but not those specific to managing risk. To fill this gap in the literature, we examine the relationship between the risk management committees and bankruptcy risk. In this study, the researcher wanted to examine whether the existence of risk management committee affects the use of negative tone as a form of verbal risk disclosure.

This study uses an observation of 4359 firms listed in the Indonesian Stock Exchange years 2010-2018 and got 2136 samples through purposive sampling. This study employs ordinary least square regression analysis to prove our hypothesis. Our main finding suggests that firms with a standalone risk management committee are significantly related to the firm's textual disclosure. It occurs since the risk management committee, as part of a board which is highly concerned about the firm's risk, can disclose more risk to investors to get positive feedback. We also have several additional analyses using sub-samples of the finance industry and high-tech industry. Our findings can be an input for policy- 
makers regarding the implementation of stand-alone risk management committees on public companies for better firm risk disclosure for any related stakeholders.

The next section of this paper has the following structure: Section 2 will explain the development of the hypothesis; Section 3 will explain the sample and variables used in the study; Section 4 will explain the results; and Section 5 will provide conclusions of the study.

\section{Hypothesis Development}

As technology develops, content analysis methods are also growing. By using the the text mining method, the characteristics of a text can be easily assessed. Several previous studies have shown positive results that tone (Lang and Lundholm 2000; Henry 2008; Davis et al. 2015; Rogers et al. 2011) can influence stakeholder economic decisions. The decisions taken by these stakeholders can certainly have an impact on the company's future performance, positively or negatively. Several studies have argued that negative tones illustrate company pessimism (Loughran and McDonald 2011; Rogers et al. 2011). Furthermore, the negative tone is considered to contain risks for investors over the uncertainty of the company's performance in the future (Kravet and Muslu 2013; Bonsall and Miller 2016) which, in this study, is called the risk-contained tone. On the other hand, there is research that states that there is no relationship between the tone and performance of the company (Tailab and Burak 2018) because according to the study, the financial statements made by the company are only a formality, without paying too much attention to the current state of the company.

Ideally, if the company exposes too much risk in its reports, it will increase investors' knowledge about the risks of the company that were not previously exposed. Investors will consider these risks when making decisions. Risks that cannot be handled properly can have an impact on the company's performance in the future. Company performance itself is a measure to see the extent to which the company's achievements are in good condition at a certain time. (Memon et al. 2012) added that the company's performance is a description of the achievements that the company has achieved with the aim of gaining trust from outside parties. In addition, investors' economic decisions that are less supportive can also have an impact on company performance.

The existence of a risk management committee has become more important since the post-financial crisis, as well as the bankruptcy phenomenon in the past. A worldwide survey showed that 85 percent of financial institutions reported periodic reviews of the entity's asset management reports by their board of directors in 2010, a 12 percent increase compared to 2008 (Deloitte 2011). This suggests that more board members are currently active within the company in risk management actions. To overcome this problem, company board members began to create new structures in the organization to support the company's risk-monitoring process (Beasley et al. 2009). Risk management is one of the specialized skills that businesses need to create better management officers who have the greatest responsibility for overseeing the company's strategic policies and activities, and that means the greatest responsibility for controlling the proper implementation of corporate risk management. The system relies heavily on the commissioners (KNKG 2012). The risk management committee (RMC) can be formed by the Board of Commissioners to ensure that the implementation of risk management functions properly and minimizes the risk of bankruptcy.

In Indonesia, the formation of RMC is mandated for companies engaged in the banking sector because this sector has more complex risks compared to other sectors. Most of the academic literature on RMC was also conducted in the banking sector (Aebi et al. 2012; Hines and Peters 2015). For other sectors, the establishment of the RMC is still voluntary. However, many companies outside the banking sector appear to have RMCs to improve the quality of their risk management. Brown et al. (2009) showed that due to the increasingly complex business risk conditions that also occur in the non-financial industry, there is a need for corporate governance that focuses specifically on risk management practices, such as through the establishment of an RMC. It is hoped that the formation of a special committee such as the RMC which focuses specifically on risk management is expected to be filled with more skilled members who have in-depth knowledge of risk management 
(Choi 2013; Fraser and Henry 2007). The establishment of an RMC can improve board risk monitoring because the RMC can dedicate its resources to evaluating risk appetite, risk profiling, and validating the company's internal controls (Moore and Brauneis 2008). This research will show that the existence of a management committee will be related to firm textual risk disclosure. It will be higher since the RMC will give more risk disclosure and assessment, or lower since the existence of RMC can manage the risk disclosure to mitigate the stakeholder's risk perception.

Hypothesis 1 (H1). There is a relationship between the risk management committee and riskcontained tone in the company's MDEA report.

\section{Research Design}

\subsection{Sample and Source of Data}

The sample in this study covers the period 2010-2018 and consists of companies listed on the Indonesian Stock Exchange (IDX). The information was collected through the company's annual report by hand-collection and the ORBIS database. Detail regarding the data resources is available in Table 1 . We applied sample selection criteria to reach our final sample. We excluded all of the missing variables. After applying these criteria, our final sample included 2136 firm-year observations.

Table 1. Sample selection criteria.

\begin{tabular}{cl}
\hline Description & Total \\
\hline Initial observations & 4359 observations \\
\hline Excluded: Firms with missing data & 2223 observations \\
\hline Final Observations & 2136 observations \\
\hline
\end{tabular}

We provide the sample distribution of this research in Table 2. Overall, there are still big gaps for each company within industries which have a risk management committee and those which do not. There are still 70.11\% of companies in Indonesia which do not have risk management committees, although the regulation is already applied. Firms in an industry with high complexity are more likely to have RMC to show their serosity to conduct good corporate governance.

Table 2. Sample distribution.

\begin{tabular}{lcccccc}
\hline \multirow{2}{*}{ Industry } & \multicolumn{2}{c}{ RMC } & \multicolumn{2}{c}{ Non-RMC } & \multicolumn{2}{c}{ Total } \\
\cline { 2 - 7 } & $\mathbf{N}$ & $\mathbf{\%}$ & $\mathbf{N}$ & $\%$ & $\mathbf{N}$ & $\%$ \\
\hline (SIC 0) Agriculture, Forestry and Fisheries & 19 & 38.00 & 31 & 62.00 & 50 & 100 \\
\hline (SIC 1) Mining & 69 & 32.70 & 142 & 67.30 & 211 & 100 \\
\hline (SIC 2) Construction Industries & 71 & 24.40 & 220 & 75.60 & 291 & 100 \\
\hline (SIC 3) Manufacturing & 43 & 22.99 & 144 & 77.01 & 187 & 100 \\
\hline $\begin{array}{l}\text { (SIC 4) Transportation, Communications } \\
\text { and Utilities }\end{array}$ & 56 & 35.22 & 103 & 64.78 & 159 & 100 \\
\hline $\begin{array}{l}\text { (SIC 6) Finance and Real Estate } \\
\text { (SIC 5) Wholesale \& Retail Trade }\end{array}$ & 102 & 35.22 & 233 & 64.78 & 159 & 100 \\
\hline (SIC 7) Service Industries & 23 & 43.40 & 30 & 56.60 & 53 & 100 \\
\hline $\begin{array}{l}\text { (SIC 8) Health, Legal, and Educational } \\
\text { Services and Consulting }\end{array}$ & 1 & 11.11 & 8 & 88.89 & 9 & 100 \\
\hline & 510 & 29.89 & 1626 & 70.11 & 2136 & 100 \\
\hline
\end{tabular}




\subsection{Operational Definition and Variable Measurement}

The independent variable of this research is the risk management committee (RMC). In Indonesia, the formation of a risk management committee is still voluntary for companies outside the banking industry. Therefore, some companies have RMC and some do not. We measure RMC using a dummy variable, coded 1 if companies disclose the existence of stand-alone RMC, and 0 if otherwise (Abdullah and Shukor 2017; Yatim 2009).

The dependent variable of this study is risk-contained tone data. We use a list of words that tend to be negative and categorized as risk (Kravet and Muslu 2013; Bonsall and Miller 2016) which is contained in the MD\&A report using the text-mining method. Those risk-contained tones might indicate some possible risk of firm performance. In this research, we follow the approach of Kravet and Muslu (2013), which was also used by Bonsall and Miller (2016) to recognize and control the proportion of terms used in statements containing risk by looking at how much negative tone was used in the text (RISKDISC).

According to Kravet and Muslu (2013), RISKDISC is defined as the existence of risk sentences with a negative tone. First, the sentences are categorized into risk sentences, then those risk sentences are selected again and categorized as risk disclosure if they contain a negative tone. The number of negative tones from selected risk sentences will be used as variables. We predict that more intensive use of negative tone will be associated with a higher cost of debt. The complete steps to measure the negative tone or content analysis is explained in the Appendix B.

Based on previous literature, we use several control variables (Abbott et al. 2003; Duellman et al. 2015; Hay et al. 2008; Karim et al. 2016). The control variables are the board of commissionaire size (COM); board of director size (DIR), the proportion of independent commissionaire (INDCOMM), BIG 4 auditors using dummy variables (BIG4), firm sizes from the natural logarithm of the total asset (FIRMSIZE), firm age from the number of years since the incorporation date until the observed year, firm performance from return on assets (ROA), firm leverage (LEVERAGE), and loss using the dummy variable (LOSS). Before analyzing the data, we winsorized our financial variables at $1 \%$ and $99 \%$ levels. The detail operational definition of variable is included in Appendix A.

\subsection{Methodology}

This study uses two regression models, namely, the ordinary least square (OLS) and OLS, with a cluster model approach by Petersen (2009). The researchers also use year and industry fixed-effects to control for differences in economic conditions and industry characteristics. The software used in this research is Stata 14.0. To test our hypotheses, we use the following research models:

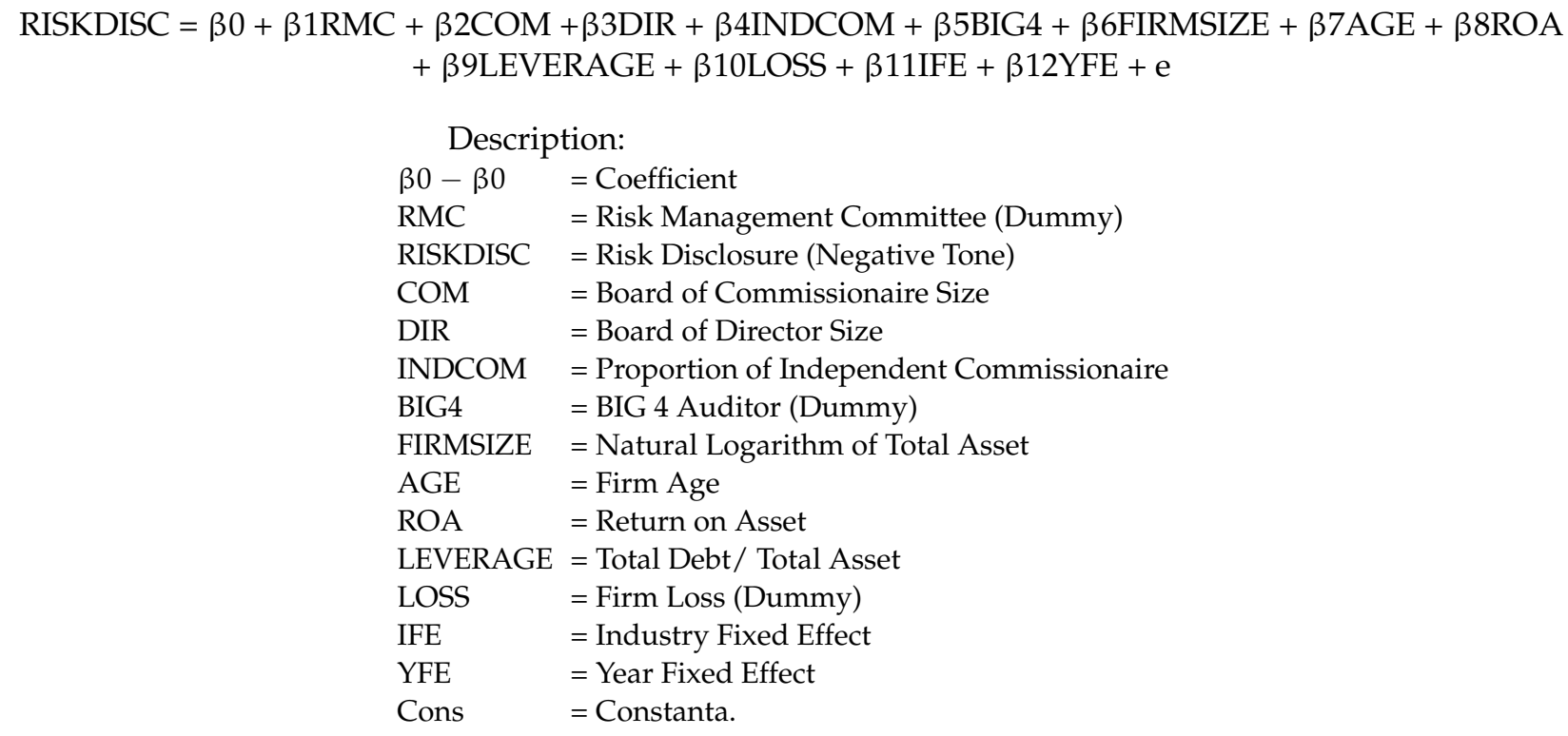




\section{Result}

\subsection{Descriptive Statistics and Univariate Comparison}

Table 3 shows the descriptive statistics for all variables used in our models. Table 3 shows the descriptive statistics for all variables used in our models. The mean value of RISKDISC is 3.016. The median value of RMC is 0 , which means more than half of the observations have zero value or no risk management committee. Furthermore, the mean value of several control variables, such as COM is 4.387, DIR is 4.965, INDCOM 0.367, LEVERAGE 0.527, FIRMSIZE 28.661, AGE 31.361, LOSS 0.198, ROA 6.406, and BIG4 0.426.

Table 3. Descriptive statistics.

\begin{tabular}{lcccccc}
\hline & $\mathbf{N}$ & Mean & Std. Dev & Median & Minimum & Maximum \\
\hline RISKDISC & 1037 & 20.565 & 1.226 & 20.516 & 17.910 & 24.334 \\
RMC & 1037 & 0.299 & 0.458 & 0.000 & 0.000 & 1.000 \\
COM & 1037 & 2.829 & 6.754 & 4.000 & 2.000 & 8.000 \\
DIR & 1037 & 2.225 & 4.323 & 2.197 & 2.000 & 9.000 \\
INDCOM & 1037 & 0.367 & 0.125 & 0.360 & 0.000 & 0.667 \\
LEVERAGE & 1037 & 0.490 & 0.219 & 0.482 & 0.073 & 1.266 \\
FIRMSIZE & 1037 & 29.023 & 1.491 & 28.948 & 25.401 & 32.339 \\
AGE & 1037 & 3.371 & 0.595 & 3.466 & 1.386 & 4.727 \\
LOSS & 3505 & 0.230 & 0.421 & 0.000 & 0.000 & LOSS \\
ROA & 1037 & 4.192 & 8.745 & 3.189 & -20.313 & 37.049 \\
BIG4 & 1037 & 0.502 & 0.500 & 1.000 & 0.000 & 1.000 \\
CEOAGE & 1037 & 0.246 & 0.431 & 0.000 & 0.000 & 1.000 \\
\hline
\end{tabular}

Table 4 shows the Pearson correlation matrix among the variables used in this study. The existence of a risk management committee (RMC) shows a significant negative relationship to risk disclosure (RISKDISC). This occurred according to the expectations we built, that the risk management committee will impact the firm's risk disclosure.

Table 4. Pearson correlations.

\begin{tabular}{|c|c|c|c|c|c|c|c|}
\hline \multicolumn{8}{|c|}{ Panel A: From Variable RMC to FIRMSIZE } \\
\hline & (1) & $(2)$ & (3) & (4) & (5) & (6) & (7) \\
\hline \multicolumn{8}{|l|}{ [1] RMC } \\
\hline [2] RISKDIC & $0.170^{* * *}$ & & & & & & \\
\hline [3] COM & $0.518^{* * *}$ & $0.155^{* * *}$ & & & & & \\
\hline [4] DIR & -0.013 & 0.026 & -0.019 & & & & \\
\hline [5] INDCOM & $0.337^{* * *}$ & $0.068^{* *}$ & $0.320^{* * *}$ & $-0.079 * *$ & & & \\
\hline [6] BIG4 & $-0.159 * * *$ & $0.216^{* * *}$ & $-0.085^{* * *}$ & $0.094^{* * *}$ & $-0.201 * * *$ & & \\
\hline [7] FIRMSIZE & $0.069 * *$ & 0.021 & -0.012 & -0.048 & $0.105^{* * *}$ & 0.026 & \\
\hline [8] AGE & $0.695^{* * *}$ & $0.198^{* * *}$ & $0.604^{* * *}$ & -0.003 & $0.434^{* * *}$ & $-0.121^{* * *}$ & $0.170 * * *$ \\
\hline [9] ROA & $0.094^{* * *}$ & $-0.069^{* *}$ & $0.228 * * *$ & -0.026 & $0.079 * *$ & $0.055 *$ & -0.006 \\
\hline [10] LEVERAGE & $0.269 * * *$ & 0.032 & $0.191 * * *$ & 0.027 & $0.157^{* * *}$ & -0.017 & $-0.178^{* * *}$ \\
\hline [11] LOSS & $0.061 * *$ & -0.015 & $-0.054 *$ & $-0.096^{* * *}$ & 0.042 & $-0.067^{* *}$ & 0.023 \\
\hline \multicolumn{8}{|c|}{ Panel B: From Variable FIRMSIZE to MTB } \\
\hline & [8] & [9] & [10] & [11] & & & \\
\hline \multicolumn{8}{|l|}{ [8] FIRMSIZE } \\
\hline [9] FIRMAGE & $0.071 * *$ & & & & & & \\
\hline$[10] \mathrm{OCF}$ & $0.175^{* * *}$ & $0.070^{* *}$ & & & & & \\
\hline [11] MTB & -0.047 & $-0.091^{* * *}$ & $0.224^{* * *}$ & & & & \\
\hline
\end{tabular}

$p$-values in parentheses. ${ }^{*} p<0.1,{ }^{* *} p<0.05,{ }^{* * *} p<0.01$.

\subsection{Risk Management Committee and Risk Disclosure}

Table 5 presents the results of OLS regression to test the association between the risk management committee (RMC) and the risk disclosure (RISKDISC) of firms using the tone 
of the text with all control variables. The existence of a risk management committee in a firm is positively related to the risk disclosure, with a coefficient of 0.153 and 0.01 significance level. It means that the risk management committee is beneficial to assess and disclose more risk through the company's report. This result is in line with previous research by Abdullah and Shukor (2017) that the existence of a standalone risk management committee is positively related to risk management disclosure. This result supports the hypothesis.

Table 5. Risk management committee and negative tone.

\begin{tabular}{|c|c|}
\hline & RISKDISC \\
\hline RMC & $\begin{array}{c}0.153^{* * *} \\
(2.63)\end{array}$ \\
\hline $\mathrm{COM}$ & $\begin{array}{l}0.014 \\
(1.10)\end{array}$ \\
\hline DIR & $\begin{array}{l}-0.020 * \\
(-0.177)\end{array}$ \\
\hline INDCOMM & $\begin{array}{l}-0.003 \\
(-2.15)\end{array}$ \\
\hline BIG4 & $\begin{array}{c}0.090 * \\
(2.20)\end{array}$ \\
\hline FIRMSIZE & $\begin{array}{c}0.133^{* * *} \\
(8.68)\end{array}$ \\
\hline AGE & $\begin{array}{l}0.002 \\
(1.30)\end{array}$ \\
\hline $\mathrm{ROA}$ & $\begin{array}{c}-0.005^{* *} \\
(-2.47)\end{array}$ \\
\hline LEVERAGE & $\begin{array}{l}-0.006 \\
(-0.12)\end{array}$ \\
\hline LOSS & $\begin{array}{l}-0.041 \\
(-0.74)\end{array}$ \\
\hline Industry Fixed Effect & Included \\
\hline Year Fixed Effect & Included \\
\hline _cons & $\begin{array}{c}-1.022^{* *} \\
(-2.48)\end{array}$ \\
\hline r2 & 0.470 \\
\hline r2_a & 0.464 \\
\hline$N$ & 2136 \\
\hline
\end{tabular}

Several control variables in this research also showed a significant result. Corporate governance, including the director size (DIR) and the proportion of independent commissioners (INDCOMM) showed a negative and significant relationship to risk disclosure (RISKDISC). The company auditor (BIG4) and firm size (FIRMSIZE) shows a positive significant relationship to firm risk disclosure (RISKDISC). It indicates that bigger audit firms and bigger companies are associated to higher risk disclosure. However, firm performance (ROA) has a negative and significant relationship to risk disclosure (RISK). It may indicate that firms with good performance expose less risk to their corporate disclosure.

\subsection{Risk Management Committee, Risk Disclosure and Corporate Governance}

Furthermore, Table 6 shows the results of the risk management committee and negative tone moderated with some governance variables, such as director size, independent commissioner, and firm size. These results indicate that firms with better corporate governance, such as the director size and independent commissioner size, strengthen the relationship between the risk management committee and risk disclosure, as well as firm's size, which indicates that in a bigger firm, the existence of a risk management committee is more effective than the firm's risk disclosure. 
Table 6. Risk management committee, director size, independent director, and firm size.

\begin{tabular}{|c|c|c|c|}
\hline & $\begin{array}{c}\text { (1) } \\
\text { RISKDISC }\end{array}$ & $\begin{array}{c}(2) \\
\text { RISKDISC }\end{array}$ & $\begin{array}{c}(3) \\
\text { RISKDISC }\end{array}$ \\
\hline $\mathrm{RMC}$ & $\begin{array}{c}0.653^{* * *} \\
(3.16)\end{array}$ & $\begin{array}{c}0.492^{* * *} \\
(3.99)\end{array}$ & $\begin{array}{c}3.561 * * \\
(2.33)\end{array}$ \\
\hline RMC_DIR & $\begin{array}{c}-0.095^{* *} \\
(-2.30)\end{array}$ & & \\
\hline RMC_INDCOM & & $\begin{array}{c}-0.190^{* * *} \\
(-2.93)\end{array}$ & \\
\hline RMC_FIRMSIZE & & & $\begin{array}{c}-0.115^{* *} \\
(-2.22)\end{array}$ \\
\hline $\mathrm{COM}$ & $\begin{array}{l}0.015 \\
(1.16)\end{array}$ & $\begin{array}{c}0.027^{* *} \\
(2.10)\end{array}$ & $\begin{array}{l}0.020 \\
(1.56)\end{array}$ \\
\hline DIR & $\begin{array}{l}-0.018 \\
(-1.30)\end{array}$ & $\begin{array}{c}-0.036^{* * *} \\
(-2.63)\end{array}$ & $\begin{array}{c}-0.034^{* *} \\
(-2.54)\end{array}$ \\
\hline INDCOMM & $\begin{array}{c}-0.003^{* *} \\
(-2.11)\end{array}$ & $\begin{array}{l}-0.002 \\
(-1.20)\end{array}$ & $\begin{array}{c}-0.003^{* *} \\
(-2.08)\end{array}$ \\
\hline BIG4 & $\begin{array}{c}0.098^{* *} \\
(2.55)\end{array}$ & $\begin{array}{c}0.095^{* *} \\
(2.48)\end{array}$ & $\begin{array}{c}0.090 * * \\
(2.33)\end{array}$ \\
\hline FIRMSIZE & $\begin{array}{c}0.134^{* * *} \\
(7.71)\end{array}$ & $\begin{array}{c}0.138^{* * *} \\
(7.85)\end{array}$ & $\begin{array}{c}0.150 * * * \\
(8.34)\end{array}$ \\
\hline AGE & $\begin{array}{l}0.001 \\
(0.89)\end{array}$ & $\begin{array}{l}0.001 \\
(1.02)\end{array}$ & $\begin{array}{l}0.001 \\
(0.97)\end{array}$ \\
\hline ROA & $\begin{array}{l}-0.003 \\
(-1.62)\end{array}$ & $\begin{array}{l}-0.004 \text { * } \\
(-1.95)\end{array}$ & $\begin{array}{l}-0.004 * \\
(-1.77)\end{array}$ \\
\hline LEVERAGE & $\begin{array}{l}-0.034 \\
(-0.52)\end{array}$ & $\begin{array}{l}-0.045 \\
(-0.70)\end{array}$ & $\begin{array}{l}-0.032 \\
(-0.50)\end{array}$ \\
\hline LOSS & $\begin{array}{l}-0.004 \\
(-0.07)\end{array}$ & $\begin{array}{l}-0.012 \\
(-0.21)\end{array}$ & $\begin{array}{l}-0.009 \\
(-0.17)\end{array}$ \\
\hline Industry & Included & Included & Included \\
\hline Year & Included & Included & Included \\
\hline _cons & $\begin{array}{c}-1.086^{* *} \\
(-2.25)\end{array}$ & $\begin{array}{c}-1.179 * * \\
(-2.44)\end{array}$ & $\begin{array}{c}-1.472 * * * \\
(-2.96)\end{array}$ \\
\hline r2 & 0.478 & 0.478 & 0.477 \\
\hline r2_a & 0.471 & 0.471 & 0.471 \\
\hline $\bar{N}$ & 2136 & 2136 & 2136 \\
\hline
\end{tabular}

\subsection{Risk Management Committee, Risk Disclosure and Industry Technology}

For further analysis, we provide an analysis for firms in a different level of the industry. Table 7 presents the results of OLS regression in examining the association between the risk management committee and risk-contained tone between four levels of technology. Tech 1 is the industry with a low level of technology, and Tech 4 is the industry with a high level of technology. All observations in this study were divided into the lowest level of technology, which was included in TECH 4 with 243 observations, TECH 3 with 371 observation, TECH 2 with 525 observations, and TECH 1 with 1006 observations. For sub-sample TECH 4, the RMC is negatively significant to risk disclosure with a coefficient of 0.677 and significant level of 0.05 . It indicates that for firms in a lower level of technology, risk management committees disclose less risk. However, firms with a high level of technology in TECH 1 are positively significant, which means that a high-level industry has a higher risk of being disclosed. 
Table 7. Industry technology levels.

\begin{tabular}{|c|c|c|c|c|}
\hline & $\begin{array}{c}\text { (TECH 1) } \\
\text { RISKDISC }\end{array}$ & $\begin{array}{c}\text { (TECH 2) } \\
\text { RISKDISC }\end{array}$ & $\begin{array}{c}\text { (TECH 3) } \\
\text { RISKDISC }\end{array}$ & $\begin{array}{l}\text { (TECH 4) } \\
\text { RISKDISC }\end{array}$ \\
\hline $\mathrm{RMC}$ & $\begin{array}{c}0.296^{* * *} \\
(5.19)\end{array}$ & $\begin{array}{l}0.059 \\
(0.37)\end{array}$ & $\begin{array}{l}0.069 \\
(0.42)\end{array}$ & $\begin{array}{c}-0.677^{* *} \\
(-2.47)\end{array}$ \\
\hline $\mathrm{COM}$ & $\begin{array}{l}0.004 \\
(0.26)\end{array}$ & $\begin{array}{l}0.038 \\
(1.39)\end{array}$ & $\begin{array}{l}-0.006 \\
(-0.20)\end{array}$ & $\begin{array}{c}0.139^{* * *} \\
(3.23)\end{array}$ \\
\hline DIR & $\begin{array}{l}0.019 \\
(1.17)\end{array}$ & $\begin{array}{c}-0.073^{* *} \\
(-2.58)\end{array}$ & $\begin{array}{l}-0.044 \\
(-1.64)\end{array}$ & $\begin{array}{l}-0.086^{*} \\
(-1.75)\end{array}$ \\
\hline INDCOMM & $\begin{array}{l}-0.000 \\
(-0.13)\end{array}$ & $\begin{array}{l}-0.004 \\
(-1.39)\end{array}$ & $\begin{array}{l}-0.002 \\
(-0.61)\end{array}$ & $\begin{array}{l}-0.003 \\
(-0.58)\end{array}$ \\
\hline BIG4 & $\begin{array}{l}0.057 \\
(1.12)\end{array}$ & $\begin{array}{l}-0.035 \\
(-0.38)\end{array}$ & $\begin{array}{c}0.256^{* * *} \\
(3.25)\end{array}$ & $\begin{array}{c}0.339 * * \\
(2.01)\end{array}$ \\
\hline FIRMSIZE & $\begin{array}{c}0.128^{* * *} \\
(5.27)\end{array}$ & $\begin{array}{c}0.233^{* * *} \\
(6.61)\end{array}$ & $\begin{array}{c}0.128^{* * *} \\
(3.57)\end{array}$ & $\begin{array}{l}-0.024 \\
(-0.42)\end{array}$ \\
\hline AGE & $\begin{array}{l}0.000 \\
(0.36)\end{array}$ & $\begin{array}{l}-0.000 \\
(-0.12)\end{array}$ & $\begin{array}{l}-0.002 \\
(-0.45)\end{array}$ & $\begin{array}{c}0.012^{* * *} \\
(2.61)\end{array}$ \\
\hline ROA & $\begin{array}{c}-0.007^{* *} \\
(-2.39)\end{array}$ & $\begin{array}{l}0.003 \\
(0.72)\end{array}$ & $\begin{array}{l}-0.009 \\
(-1.59)\end{array}$ & $\begin{array}{l}-0.005 \\
(-0.63)\end{array}$ \\
\hline LEVERAGE & $\begin{array}{l}0.007 \\
(0.08)\end{array}$ & $\begin{array}{l}-0.129 \\
(-1.25)\end{array}$ & $\begin{array}{l}-0.440 \text { * } \\
(-1.96)\end{array}$ & $\begin{array}{c}0.594^{* * *} \\
(3.28)\end{array}$ \\
\hline LOSS & $\begin{array}{l}-0.107 \\
(-1.31)\end{array}$ & $\begin{array}{l}0.074 \\
(0.72)\end{array}$ & $\begin{array}{l}-0.151 \\
(-1.10)\end{array}$ & $\begin{array}{l}-0.024 \\
(-0.11)\end{array}$ \\
\hline $\begin{array}{c}\text { INDUSTRY } \\
\text { YEAR } \\
\text { _cons }\end{array}$ & $\begin{array}{c}\text { Included } \\
\text { Included } \\
-1.053 \\
(-1.55)\end{array}$ & $\begin{array}{c}\text { Included } \\
\text { Included } \\
-3.557^{* * *} \\
(-3.71)\end{array}$ & $\begin{array}{c}\text { Included } \\
\text { Included } \\
-0.895 \\
(-0.91)\end{array}$ & $\begin{array}{c}\text { Included } \\
\text { Included } \\
2.229 \\
(1.39)\end{array}$ \\
\hline r2 & 0.520 & 0.412 & 0.555 & 0.492 \\
\hline r2_a & 0.508 & 0.388 & 0.527 & 0.439 \\
\hline $\bar{N}$ & 1006 & 525 & 371 & 234 \\
\hline
\end{tabular}

\subsection{Risk Management Committee, Risk Disclosure and Quartal Analysis}

Further, we conducted a quartal analysis as the robustness analysis in the Table 8 . We divide the sample into four groups based on the sample distribution of risk disclosure (NTONE). Quarter 1 is for the negative tone, which is less than 11, with a total sample of 519. Quarter 2 is for the negative tone between 11 and 28, with a total sample of 482. Quarter 3 is for the negative tone between 29 and 45, with a total sample of 481 . Quarter 4 is for the negative tone of more than 45 , with a total sample of 518 . The results show that the coefficient on RISKDISC is positive and statistically significant at the 1 percent level only for the subsample in quartal 4. It means that the standalone risk management committee is associated to firms with higher levels of risk disclosure. It supports the main regression analysis. 
Table 8. Quartal analysis.

\begin{tabular}{|c|c|c|c|c|}
\hline & $\begin{array}{c}\text { (1) } \\
\text { RISKDISC }\end{array}$ & $\begin{array}{c}(2) \\
\text { RISKDISC }\end{array}$ & $\begin{array}{c}\text { (3) } \\
\text { RISKDISC }\end{array}$ & $\begin{array}{c}(4) \\
\text { RISKDISC }\end{array}$ \\
\hline $\mathrm{RMC}$ & $\begin{array}{l}-0.076 \\
(-0.58)\end{array}$ & $\begin{array}{l}0.015 \\
(0.39)\end{array}$ & $\begin{array}{l}0.020 \\
(0.97)\end{array}$ & $\begin{array}{c}0.082^{* * *} \\
(2.82)\end{array}$ \\
\hline $\mathrm{COM}$ & $\begin{array}{l}0.023 \\
(0.96)\end{array}$ & $\begin{array}{l}0.008 \\
(0.87)\end{array}$ & $\begin{array}{l}-0.002 \\
(-0.48)\end{array}$ & $\begin{array}{l}0.002 \\
(0.34)\end{array}$ \\
\hline DIR & $\begin{array}{l}-0.026 \\
(-1.21)\end{array}$ & $\begin{array}{l}0.008 \\
(1.12)\end{array}$ & $\begin{array}{l}-0.001 \\
(-0.17)\end{array}$ & $\begin{array}{l}0.007 \\
(1.06)\end{array}$ \\
\hline INDCOMM & $\begin{array}{l}-0.003 \\
(-1.10)\end{array}$ & $\begin{array}{l}0.001 \\
(0.99)\end{array}$ & $\begin{array}{l}-0.000 \\
(-0.05)\end{array}$ & $\begin{array}{l}-0.001 \\
(-1.15)\end{array}$ \\
\hline BIG4 & $\begin{array}{l}0.057 \\
(0.76)\end{array}$ & $\begin{array}{l}0.025 \\
(0.99)\end{array}$ & $\begin{array}{l}-0.017 \\
(-1.31)\end{array}$ & $\begin{array}{c}-0.091 * * * \\
(-3.84)\end{array}$ \\
\hline FIRMSIZE & $\begin{array}{c}0.065^{* *} \\
(2.47)\end{array}$ & $\begin{array}{l}-0.005 \\
(-0.43)\end{array}$ & $\begin{array}{c}0.011^{* *} \\
(2.10)\end{array}$ & $\begin{array}{c}0.052^{* * *} \\
(5.28)\end{array}$ \\
\hline AGE & $\begin{array}{l}0.000 \\
(0.03)\end{array}$ & $\begin{array}{l}0.000 \\
(0.16)\end{array}$ & $\begin{array}{l}0.000 \\
(0.90)\end{array}$ & $\begin{array}{l}-0.001 \\
(-1.51)\end{array}$ \\
\hline ROA & $\begin{array}{l}-0.008^{*} \\
(-1.72)\end{array}$ & $\begin{array}{l}-0.003^{* *} \\
(-2.43)\end{array}$ & $\begin{array}{l}-0.000 \\
(-0.35)\end{array}$ & $\begin{array}{l}-0.001 \\
(-0.47)\end{array}$ \\
\hline LEVERAGE & $\begin{array}{l}-0.078 \\
(-0.96)\end{array}$ & $\begin{array}{l}-0.029 \\
(-0.93)\end{array}$ & $\begin{array}{c}-0.044^{* * *} \\
(-2.81)\end{array}$ & $\begin{array}{l}0.034 \\
(0.65)\end{array}$ \\
\hline LOSS & $\begin{array}{l}0.084 \\
(0.89)\end{array}$ & $\begin{array}{l}-0.067 * \\
(-1.73)\end{array}$ & $\begin{array}{l}0.000 \\
(0.01)\end{array}$ & $\begin{array}{l}-0.031 \\
(-0.99)\end{array}$ \\
\hline $\begin{array}{c}\text { INDUSTRY } \\
\text { YEAR } \\
\text { _cons }\end{array}$ & $\begin{array}{c}\text { Included } \\
\text { Included } \\
-0.265 \\
(-0.37)\end{array}$ & $\begin{array}{c}\text { Included } \\
\text { Included } \\
2.966^{* * * *} \\
(10.21)\end{array}$ & $\begin{array}{c}\text { Included } \\
\text { Included } \\
3.272^{* * * *} \\
(22.57)\end{array}$ & $\begin{array}{l}\text { Included } \\
\text { Included } \\
2.498^{* * *} \\
(8.62)\end{array}$ \\
\hline r2 & 0.060 & 0.158 & 0.089 & 0.157 \\
\hline r2_a & 0.012 & 0.112 & 0.039 & 0.116 \\
\hline$N$ & 519 & 482 & 481 & 518 \\
\hline
\end{tabular}

\subsection{Risk Management Committee, Risk Disclosure and Financial Industry}

The next additional analysis is for the financial and banking industry as presented in Table 9. Since the regulation of the risk management committee is mandatory for banking since 2016, we made a sub-sample for pre- and post-regulation. Table 5 shows the result that the relation between RMC and Risk Disclosure is more significant after the regulation is applied for companies in the banking industry.

Table 9. Pre-post regulation for the financial and banking industry.

\begin{tabular}{ccc}
\hline & $\mathbf{( 1 )}$ & $\mathbf{( 2 )}$ \\
& RISKDISC & RISKDISC \\
\hline RMC & 0.248 & $0.418^{* *}$ \\
POST & $(1.37)$ & $(2.01)$ \\
& $-1.418^{* * *}$ & $-1.349^{* * *}$ \\
RMCPOST & $(-7.30)$ & $(-6.83)$ \\
& & -0.609 \\
COM & -0.030 & $(-1.47)$ \\
& $(-0.85)$ & -0.032 \\
DIR & $0.084^{* *}$ & $(-0.90)$ \\
& $(1.98)$ & $0.091^{* *}$ \\
INDCOMM & -0.003 & $(2.10)$ \\
& $(-0.55)$ & -0.002 \\
BIG4 & -0.068 & $(-0.51)$ \\
& $(-0.54)$ & -0.062 \\
& & $(-0.49)$ \\
\hline
\end{tabular}


Table 9. Cont.

\begin{tabular}{|c|c|c|}
\hline & $\begin{array}{c}\text { (1) } \\
\text { RISKDISC }\end{array}$ & $\begin{array}{c}(2) \\
\text { RISKDISC }\end{array}$ \\
\hline FIRMSIZE & $\begin{array}{l}0.059 \\
(1.10)\end{array}$ & $\begin{array}{l}0.043 \\
(0.76)\end{array}$ \\
\hline AGE & $\begin{array}{c}0.010 * * \\
(2.07)\end{array}$ & $\begin{array}{c}0.009 * \\
(1.89)\end{array}$ \\
\hline ROA & $\begin{array}{l}-0.019 * \\
(-1.65)\end{array}$ & $\begin{array}{l}-0.019 * \\
(-1.68)\end{array}$ \\
\hline LEVERAGE & $\begin{array}{c}0.506 * \\
(1.76)\end{array}$ & $\begin{array}{c}0.481 * \\
(1.66)\end{array}$ \\
\hline LOSS & $\begin{array}{l}-0.427 * \\
(-1.72)\end{array}$ & $\begin{array}{l}-0.448 * \\
(-1.82)\end{array}$ \\
\hline SIC 6 & $\begin{array}{c}0.000 \\
(.)\end{array}$ & $\begin{array}{c}0.000 \\
(.)\end{array}$ \\
\hline $\begin{array}{l}\text { YEAR } \\
\text { _cons }\end{array}$ & $\begin{array}{l}0.000 \\
0.584 \\
(0.39)\end{array}$ & $\begin{array}{l}0.000 \\
1.018 \\
(0.65)\end{array}$ \\
\hline r2 & 0.501 & 0.505 \\
\hline r2_a & 0.456 & 0.457 \\
\hline$N$ & 206 & 206 \\
\hline
\end{tabular}

\section{Conclusions}

This research investigated the relationship between risk management committees and risk-contained tone. Risk-contained tone in this research became the proxy of the firm's risk disclosure quality. This becomes an important issue, since the formation of risk management committees in Indonesia are still voluntary for most of the industry. We expect that our study can provide an input for policy-makers regarding the formation of RMC, especially in Indonesia. This research used observations of 4359 firms listed in Indonesian Stock Exchange years of 2010-2018, and got 2136 samples through purposive sampling. The quantity of negative tone of the annual report as the indicator of the textual disclosure strategy was recognized as an important reporting aspect for companies. The existence of the Risk Management Committee within a company is essential for managing those risk disclosures.

The results of this study support our hypothesis. This research gives empirical evidence that the risk management committee has a significant relationship to the firm's risk disclosure. This result supports previous research by Abdullah and Shukor (2017) As stated by several previous studies, we expect that companies establish a standalone risk management committee with a motive to disclose risk information as it benefits investors, enabling companies to better allocate resources (Abraham and Shrives 2014; Leopizzi et al. 2020; Fijalkowska and Hadro 2022). Some other interested variables also showed a significant result as predicted; for example, corporate governance showed a positive association to risk disclosure because better governance means better control. Our additional analysis also provides several insights. The relationship between the existence of the risk management committee within a company is more pronounced for companies in a high-technology industry. Besides in the specific case of Indonesia, the risk management committee is more significantly related to risk disclosure for companies in the finance and banking industry, since the regulation is only mandatory for those industries, and voluntary for other industries.

The results of this research contribute new insight to the literature through the examination of firm-specific committees related to risk, and the risk disclosure as the output. This research also provides evidence for the management of the importance of risk management committees to make firm risk management and disclosure its optimum concern. For the regulator, this finding might prompt a consideration to apply mandatory regulation for 
each public company to have a risk management committee. There are some limitations that researchers found when conducting this research. First, some companies publish their annual report in the form of pictures, and therefore, the text cannot be run in the application. Lastly, this research focuses on the setting of Indonesia as a developing country. Other countries with a similar setting might use this research as an input to regulatory bodies. Hence, future researchers from different countries with different characteristics from Indonesia might do similar research to provide richer insight. The following ressearchers can also include external environmental factors to enrich the perspective of research. It can be added onto by political, economic, social, technological, and environmental factors. Future researchers may also consider another textual risk disclosure measurement.

Author Contributions: Conceptualization, E.S.A. and I.H.; methodology, E.S.A.; software, E.S.A.; validation, E.S.A. and I.H.; formal analysis, I.H.; investigation, E.S.A. and I.H.; resources, E.S.A.; data curation, I.H.; writing-original draft preparation, E.S.A.; writing-review and editing, E.S.A.; visualization, E.S.A.; supervision, I.H.; project administration, E.S.A. All authors have read and agreed to the published version of the manuscript.

Funding: This research was funded by Direktorat Riset dan Pengabdian Masyarakat, Deputi Bidang Penguatan Riset dan Pengembangan Kementerian Riset dan Teknologi/Badan Riset dan Inovasi Nasional.

Data Availability Statement: Data sharing not applicable.

Conflicts of Interest: The authors declare no conflict of interest. There are no funders for this research.

\section{Appendix A}

Table A1. Variable definition.

\begin{tabular}{|c|c|c|c|}
\hline & Variables & Definition & Source \\
\hline $\begin{array}{l}\text { Dependent: } \\
\text { Risk Disclosure }\end{array}$ & RISKDISC & $\begin{array}{l}\text { Number of risk tones disclosed in } \\
\text { the company's annual report }\end{array}$ & Annual Report \\
\hline $\begin{array}{l}\text { Independent: } \\
\text { Risk Management } \\
\text { Committee }\end{array}$ & $\mathrm{RMC}$ & $\begin{array}{l}\text { Dummy variable, } 1 \text { if company has } \\
\text { a Risk Management Committee, } \\
\text { and } 0 \text { if not }\end{array}$ & Annual Report \\
\hline $\begin{array}{l}\text { Control: } \\
\text { Commissioner Size }\end{array}$ & $\mathrm{COM}$ & $\begin{array}{l}\text { Number of members of the board } \\
\text { of commissioners in the company }\end{array}$ & Financial Report \\
\hline $\begin{array}{l}\text { Independent } \\
\text { Commissioner }\end{array}$ & INDCOM & $\begin{array}{l}\text { Percentage of independent } \\
\text { commissioners in the company }\end{array}$ & Financial Report \\
\hline Director Size & DIR & $\begin{array}{l}\text { Number of members of the board } \\
\text { of directors in the company }\end{array}$ & Bloomberg \\
\hline Firm Size & FIRMSIZE & $\begin{array}{l}\text { Natural logarithm of total assets at } \\
\text { the end of the year }\end{array}$ & ORBIS \\
\hline Leverage & LEVERAGE & Total debt divided by total assets & ORBIS \\
\hline Firm Age & AGE & $\begin{array}{l}\text { The number of years since the } \\
\text { company was listed in IDX }\end{array}$ & ORBIS \\
\hline Growth of Assets & GROWTH & $\begin{array}{l}\text { Difference between total assets and } \\
\text { lag total assets divided by lag total } \\
\text { assets }\end{array}$ & ORBIS \\
\hline Return on Assets & $\mathrm{ROA}$ & Net income divided by total assets & ORBIS \\
\hline Loss & LOSS & $\begin{array}{l}\text { Dummy variable, } 1 \text { if net income is } \\
\text { negative, and } 0 \text { if otherwise }\end{array}$ & ORBIS \\
\hline BIG4 Auditor & BIG4 & $\begin{array}{l}\text { Dummy variable, } 1 \text { if the firm was } \\
\text { audited by a Big } 4 \text {, and } 0 \text { if } \\
\text { otherwise }\end{array}$ & Financial Report \\
\hline
\end{tabular}




\section{Appendix B \\ Data Collection Method of Risk-Contained Tone \\ Step 1: Obtaining Annual Report file}

We downloaded annual reports of all listed firms for fiscal years from 2010 until 2017 from the Indonesian Stock Exchange website (idx.co.id). Then we did content analysis from steps 2 to 3 .

\section{Step 2: Extracting risk disclosures from 10-K filings}

We searched for full sentences that involve the following risk-related keywords (where a "*' implies that suffixes are allowed): "can", "cannot", "could", "may", "might", "risk*", "uncertain*", "likely to" "subject to" "potential", "vary*", "varies", "depend", "expos*", "fluctuat", "possibl"*, susceptible", "affect", " influenc*", and " hedg". We tagged a sentence as risk disclosure if it contained at least one of the above keywords.

\section{Step 3: Analyzing the negative tone in risk disclosures}

We further categorized risk-disclosure sentences according to whether they contained a negative tone. A risk disclosure sentence is identified as having a negative tone if it includes one or more of the following keywords and their variations: "Negative" "adverse", "damage" ${ }^{* \prime \prime}$ destroy", "loss", "harm", "catastroph*", "tragic", "destruct", "significant", "serious", and "hamper".

\section{Step 4: Calculating numbers of negative tone}

The last step is calculating the numbers of negative tone which are contained in risk disclosure sentences. Those numbers will then be used as the proxy of variable negative tone (RISKDISC).

\section{References}

Abbott, Lawrence J., Susan Parker, Gary F. Peters, and Kannan Raghunandan. 2003. The Association between Audit Committee Characteristics and Audit Fees. Auditing: A Journal of Practice E Theory 22: 17-32. [CrossRef]

Abdullah, Wan Nailah, and Roshima Said. 2019. Audit and risk committee in financial crime prevention. Journal of Financial Crime 26: 223-34. [CrossRef]

Abdullah, Maizatulakma, and Zaleha Abdul Shukor. 2017. The comparative moderating effect of risk management committee and audit committee on the association between voluntary risk management disclosure and firm performance. Jurnal Pengurusan 51: 159-72. [CrossRef]

Abraham, Santhosh, and Philip J. Shrives. 2014. Improving the relevance of risk factor disclosure in corporate annual reports. The British Accounting Review 46: 91-107. [CrossRef]

Aebi, Vincent, Gabriele Sabato, and Markus Schmid. 2012. Risk management, corporate governance, and bank performance in the financial crisis. Journal of Banking $\mathcal{E}$ Finance 36: 3213-26.

Beasley, Mark S., Joseph V. Carcello, Dana R. Hermanson, and Terry L. Neal. 2009. The audit committee oversight process. Contemporary Accounting Research 26: 65-122. [CrossRef]

Bonsall, Samuel, and Brian Miller. 2016. The Impact of Narrative Disclosure Readability on Bond Ratings and the Cost of Debt Capital. Review of Accounting Studies 22: 608-43. [CrossRef]

Brown, Ian, Adam Steen, and Julie Foreman. 2009. Risk management in corporate governance: A review and proposal. Corporate Governance: An International Review 17: 546-58. [CrossRef]

Choi, Ivan. 2013. When do companies need a board-level risk management committee? In Global Corporate Governance Forum Publication. Washington: World Bank. Available online: http://documents.worldbank.org/curated/en/391041468155732466/Whendocompanies-need-aboard-level-risk-managementcommittee (accessed on 12 July 2021).

Chung, Cindy K., and James W. Pennebaker. 2011. Using Computerized Text Analysis to Assess Threatening Communications and Behavior. In Threatening Communications and Behavior: Perspectives on the Pursuit of Public Figures. The National Academy Press. Available online: https: / / www.nap.edu/read/13091/chapter/3 (accessed on 12 July 2021).

Darrat, Ali F., Stephen Gray, Jung Chul Park, and Yanhui Wu. 2016. Corporate governance and bankruptcy risk. Journal of Accounting, Auditing E Finance 31: 163-202.

Davis, Angela K., and Isho Tama-Sweet. 2012. Managers' use of language across alternative disclosure outlets: Earnings press releases versus MD\&A. Contemporary Accounting Research 29: 804-37.

Davis, Angela K., Weili Ge, Dawn Matsumoto, and Jenny Li Zhang. 2015. The effect of manager-specific optimism on the tone of earnings conference calls. Review of Accounting Studies 20: 639-73. [CrossRef] 
Deloitte. 2011. Global Risk Management Survey, Seventh Edition Navigating in a Changed World. Available online: https:/ /www.iia. $\mathrm{nl} /$ SiteFiles/Global\%20Risk\%20Management\%20Survey-7.pdf (accessed on 25 June 2021).

Duellman, Scott, Helen Hurwitz, and Yan Sun. 2015. Managerial overconfidence and audit fees. Journal of Contemporary Accounting $\mathcal{E}$ Economics 11: 148-65. [CrossRef]

Feldman, Ronen, Suresh Govindaraj, Joshua Livnat, and Benjamin Segal. 2010. Management's tone change, post earnings announcement drift and accruals. Review of Accounting Studies 15: 915-53. [CrossRef]

Fijalkowska, Justyna, and Dominika Hadro. 2022. Risk Information in Non-Financial Disclosure. Risks 10: 11. [CrossRef]

Fraile, Isabel Acero, and Nuria Alcalde Fradejas. 2012. The effect of the monitoring function and advisory function on board structure. Spanish Journal of Finance and Accounting/Revista Española de Financiación y Contabilidad 41: 9-38. [CrossRef]

Fraser, Ian, and William Henry. 2007. Embedding risk management: Structures and approaches. Managerial Auditing Journal 22: $392-409$. [CrossRef]

Frazier, Katherine Beal, Robert W. Ingram, and B. Mack Tennyson. 1984. A methodology for the analysis of narrative accounting disclosures. Journal of Accounting Research 22: 318-31. [CrossRef]

Harymawan, Iman, Fajar Kristanto Gautama Putra, Tanaya Devi Kemala Agni, and Khairul Anuar Kamarudin. 2020. Sustainability report practices in Indonesia: Context, policy, and readability. International Journal of Energy Economics and Policy 10: 438-43. [CrossRef]

Harymawan, Iman, Aditya Aji Prabhawa, Mohammad Nasih, and Fajar Kristanto Gautama Putra. 2021. Risk Management Committee, Auditor Choice and Audit Fees. Risks 9: 156. [CrossRef]

Hay, David, W. Robert Knechel, and Helen Ling. 2008. Evidence on the impact of internal control and corporate governance on audit fees. International Journal of Auditing 24: 9-24. [CrossRef]

Henry, Elaine. 2008. Are investors influenced by how earnings press releases are written? The Journal of Business Communication 45: 363-407. [CrossRef]

Hines, Chris S., and Gary F. Peters. 2015. Voluntary risk management committee formation: Determinants and short-term outcomes. Journal of Accounting and Public Policy 34: 267-90. [CrossRef]

Huang, Xuan, Siew Hong Teoh, and Yinglei Zhang. 2014. Tone management. The Accounting Review 89: 1083-113. [CrossRef]

Kahveci, Eyup. 2016. The tone of annual reports as a strategic performance management tool: Application on Turkey's Borsa Istanbul corporate governance index firms. Journal of Economics Finance and Accounting 3: 209-21.

Karim, Khondkar, Ashok Robin, and SangHyun Suh. 2016. Board structure and audit committee monitoring: Effects of audit committee monitoring incentives and board entrenchment on audit fees. Journal of Accounting, Auditing \& Finance 31: 249-76. [CrossRef]

KNKG. 2012. Guidance on Governance Based Risk Management Practice. Jakarta: Komite Nasional Kebijakan Governance. (In Bahasa)

Kothari, Sabino P., Xu Li, and James E. Short. 2009. The effect of disclosures by management, analysts, and business press on cost of capital, return volatility, and analyst forecasts: A study using content analysis. The Accounting Review 84: 1639-70. [CrossRef]

Kravet, Todd, and Volkan Muslu. 2013. Textual risk disclosures and investors' risk perceptions. Review of Accounting Studies 18: 1088-122. [CrossRef]

Lang, Mark H., and Russell J. Lundholm. 2000. Voluntary disclosure and equity offerings: Reducing information asymmetry or hyping the stock? Contemporary Accounting Research 17: 623-62. [CrossRef]

Larasati, Dyah Ayu, Melinda Cahyaning Ratri, Mohammad Nasih, and Iman Harymawan. 2019. Independent audit committee, risk management committee, and audit fees. Cogent Business \& Management 6: 1707042.

Larcker, David F., and Anastasia A. Zakolyukina. 2012. Detecting deceptive discussions in conference calls. Journal of Accounting Research 50: 495-540. [CrossRef]

Leopizzi, Rossella, Antonio Iazzi, Andrea Venturelli, and Salvatore Principale. 2020. Nonfinancial risk disclosure: The "state of the art" of Italian companies. Corporate Social Responsibility and Environmental Management 27: 358-68. [CrossRef]

Li, Feng. 2008. Annual report readability, current earnings, and earnings persistence. Journal of Accounting and Economics 45: $221-47$. [CrossRef]

Loughran, Tim, and Bill McDonald. 2011. When is a liability not a liability? Textual analysis, dictionaries, and 10-Ks. The Journal of Finance 66: 35-65. [CrossRef]

Manzaneque, Montserrat, Alba María Priego, and Elena Merino. 2016. Corporate governance effect on financial distress likelihood: Evidence from Spain. Revista de Contabilidad 19: 111-21. [CrossRef]

Memon, Fozia, Niaz Ahmed Bhutto, and Ghulam Abbas. 2012. Capital structure and firm performance: A case of textile sector of Pakistan. Asian Journal of Business and Management Sciences 1: 9-15.

Moore, Matthew A., and Michael J. Brauneis. 2008. U.S. subprime crisis: Risk management's next steps. Bank Accounting and Finance 21: $18-48$.

Oyerogba, Exekiel Oluwagbemiga. 2019. The influence of accounting information disclosure on foreign direct investment in nigerian listed companies. Management $\mathcal{E}$ Accounting Review (MAR) 18: 131-68.

Petersen, Mitchell A. 2009. Estimating standard errors in finance panel data sets: Comparing approaches. The Review of Financial Studies 22: 435-80. Available online: http:/ / www.jstor.org/stable/40056916 (accessed on 16 July 2021).

Putra, Fajar Kristanto Gautama, Iman Harymawan, Nasih Mohammad, and Agustia Dian. 2020. A quest to minimize cost of debt by utilizing human resources disclosure. Polish Journal of Management Studies 21: 342-55. [CrossRef] 
Rogers, Jonathan L., Andrew Van Buskirk, and Sarah L. C. Zechman. 2011. Disclosure tone and shareholder litigation. The Accounting Review 86: 2155-83. [CrossRef]

Seetharaman, Arumugam, Vikas Kumar Sahu, A. S. Saravanan, John Rudolph Raj, and Indu Niranjan. 2017. The impact of risk management in credit rating agencies. Risks 5: 52. [CrossRef]

Tailab, Mohamed, and Marshall J. Burak. 2018. Is the rhetorical tone in a MD\&A consistent with financial performance? Journal of Finance and Accountancy 23.

Walker, Paul Lynn, William G. Shenkir, and Thomas L. Barton. 2002. Enterprise Risk Management: Putting It all Together. Altamonte Springs: Institute of Internal Auditors Research Foundation.

Yatim, Puan. 2009. Board structures and the establishment of a risk management committee by Malaysian listed firms. Journal of Management and Governance 14: 17-36. [CrossRef] 